\title{
Cultura Cultura
}

\section{Os cavaleiros da espada de pau e os arcanjos da espada dum trovão}

\author{
A Renascença Portuguesa e a cultura democrática
}

The knights of the wooden sword and the archangels of the thunder sword: the Renascença Portuguesa and the democratic culture

\section{Adelaide Maria Muralha Vieira Machado}

\section{OpenEdition}

\section{Journals}

\section{Edição electrónica}

URL: http://journals.openedition.org/cultura/501

DOI: 10.4000/cultura.501

ISSN: 2183-2021

\section{Editora}

Centro de História da Cultura

\section{Edição impressa}

Data de publição: 1 Junho 2009

Paginação: 215-230

ISSN: 0870-4546

\section{Refêrencia eletrónica}

Adelaide Maria Muralha Vieira Machado, « Os cavaleiros da espada de pau e os arcanjos da espada dum trovão », Cultura [Online], Vol. 26 | 2009, posto online no dia 16 setembro 2013, consultado a 01 maio 2019. URL : http://journals.openedition.org/cultura/501 ; DOI : 10.4000/cultura.501 


\title{
Os cavaleiros da espada de pau \\ e os arcanjos da espada dum trovão: \\ a Renascença Portuguesa e a cultura democrática
}

\author{
Adelaide Maria Muralha Vieira Machado*
}

Quando procuramos ecos precursores em Portugal para o movimento da Renascença Portuguesa, pelo menos três nomes, entre outros, são de destacar: Guerra Junqueiro, Sampaio Bruno e Basílio Teles. Enquadrados num posicionamento político militante e alternativo à monarquia (só após o Ultimato inglês no caso de Junqueiro, mas questionando as correntes materialista e positivista), eram activistas e publicistas mas também pensadores e filósofos que procuravam dar sentido a uma nova identidade portuguesa. Em termos culturais, situavam-se na charneira ou comungavam do simbolismo decadentista e nefelibata, e do naturalismo mais ou menos romântico, sob a influência de Victor Hugo e Tolstoi, mas também de Proudhon ou Jaurès. Todos participaram nas lutas pela implantação da República e todos se desiludiram com o seu andamento político.

A busca de justiça social dentro do ideal libertário que acompanhou estas três figuras reflectida em obra publicada e nas tertúlias que animaram à sua volta, assim como os seus temas favoritos (a pátria enquanto princípio espiritual de coesão e harmonia, o sebastianismo como busca e solução para o ser português, bem como os problemas que transcendiam as categorias racionais tais como o mal, o nascimento, a morte, a identidade), encontraram seguimento na Renascença Portuguesa e inspiraram os seus fundadores. Seguindo o órgão divulgador do movimento, A Águia, damos conta desta influência, também baseada na admiração de condutas pessoais e políticas, insuspeitas.

Leonardo Coimbra, a propósito do trabalho de Basílio Teles sobre o Livro de Job, em torno da problemática do mal, identificando-se com o autor ao identificá-lo com o criacionismo bergsoniano, escreveu:

Religião e Ciência são impotentes perante um Bem e um Mal para elas irredutíveis e absolutos. Um criacionismo moral verá na dualidade Espírito-Natureza o motivo da sua acção e o valor da sua realidade. Na continuidade vivida do esforço moral encontrará Deus, o inces-

Seminário Livre de História das Ideias, Centro de História da Cultura da Faculdade de Ciências Sociais e Humanas da Universidade Nova de Lisboa. 
sante acréscimo dos domínios espirituais (...). O homem tem a responsabilidade, livremente tomada de moralizar a natureza, isto é, as paixões, a inteligência, os instintos, a cegueira. ${ }^{1}$

Reverenciando a postura de Basílio Teles, como o exemplo da pessoa e do político que se procurava, e que a revista pretendia ajudar a perfilar, terminava o artigo apelando à juventude para que se revisse naquela figura² .

Guerra Junqueiro e Sampaio Bruno foram também, postumamente, homenageados pela revista com números a eles especialmente dedicados, participados pelos principais colaboradores e representantes das letras portuguesas.

No número dedicado a Junqueiro, Leonardo Coimbra dedicou várias páginas à análise crítica da obra do poeta, filósofo e pensador. Distanciando-se do naturalismo do qual Junqueiro, segundo ele, nunca se libertara, elogiava sobretudo o poeta de A Pátria, como o momento de libertação interior e visionária.

Deixamos de lado o que classificamos de parte polémica ou combativa para nos demorarmos gostosamente na alegria espiritual da parte de enternecimento e lírica contemplação e na parte do espiritualismo reconstrutivo. (...) Há mesmo na Pátria... visões proféticas, messiânicas, dum formidável volume de humanas realidades metafísicas (..... ${ }^{3}$

Quanto ao pensador, Coimbra lembrava o motivo por que só na criação poética aquele autor conseguia por vezes a liberdade total, fora do determinismo intelectualista e formal, e que o colocava a par de Cervantes, Shakespeare, Dante ou Camões. O idealismo evolucionista de Junqueiro contrastava com a ideia de ausência de princípio e fim, progresso ou decadência, interligação primordial de Espírito-Matéria, que presidiam à filosofia de Leonardo e dimensionavam a sua ideia de liberdade.

Movimento contínuo, élan vital eram passíveis de recomeço, renovação ou queda a cada instante no tempo concreto ou psicológico, isto é, a espiral como percurso necessário da humanidade em tempo abstracto perdia a validade perante a força do momento vital, que tornava cada um possuidor do conhecimento da liberdade absoluta, no plano espiritual.

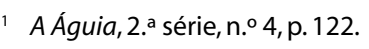

2 "É como se perdidos num jardim, cheio de monstros requintados, de repente os nossos olhos vissem o sólido raizame de algum carvalho, ou como se, num quente salão perfumado, entrasse de repente a rajada da Montanha. Abençoado o austero homem, que é um grande exemplo à nossa mocidade."; A Águia, 2. ${ }^{\text {a }}$ série, n. ${ }^{\circ}$, p. 123.

3 A Águia, 3.a série, n. ${ }^{\circ s} 13-14$ a 17-18, p. 18. 
Nesse sentido, com Sampaio Bruno o encontro de ideias era maior, e a sua influência foi clara quer no poeta da Renascença, Teixeira de Pascoaes, quer no seu filósofo de serviço, Leonardo. Também em artigo de homenagem póstuma, depois de gabar o brilhante combate de Bruno contra o positivismo, em Brasil Mental, apresentava-o como precursor de Bergson de Matéria e Memória, no esforço de entender e dar sentido ao universo e ao homem, a Deus e à existência do mal. A questão de a unidade cósmica das pluralidades humanas só ser possível no absoluto divino era partilhada por estes pensadores.

A queda de Deus pelo encontro com o mal como mistério divino, correspondente a uma ruptura nas consciências humanas, era também teorizada por Pascoaes; digamos que, desta forma, toda a redenção humana seria sempre um contributo para a redenção divina ${ }^{4}$.

Acompanhando o filósofo e pedagogo francês, na necessária interacção entre os planos substanciais, na dualidade espírito e matéria, que enformavam a acção e o real concreto, descortinava: "O absoluto é o alimento de nossas almas, e se ao termo do nosso cogitar sempre encontramos o relativo, é, felizmente, porque sempre a realidade é actividade socialista - o eu cooperando com o vós." ${ }^{5}$

Através destas homenagens feitas na revista, para além de permitir descodificar a importância e os limites das influências recebidas, levantava-se um pouco o véu da episteme do movimento da Renascença Portuguesa.

Continuando nesse caminho, passamos agora ao trio fundador: Teixeira de Pascoaes, Leonardo Coimbra e Jaime Cortesão. Em 1906, encontravam-se os três no Porto, Pascoaes já como advogado e com 29 anos, Coimbra com 23 e a frequentar a Academia Politécnica, e Cortesão com 22 anos, a estudar na Escola Médico-Cirúrgica. Nesse ano, Leonardo e Pascoaes conhecem-se e têm uma longa conversa. Segundo este último, em carta a Sant'Anna Dionísio, a amizade que os uniu para o resto da vida começou nesse encontro, o único, aliás, antes do processo que deu início ao movimento da Renascença.

Um ano depois, Jaime Cortesão, Leonardo Coimbra e Álvaro Pinto ${ }^{6}$ fundaram uma revista de curta duração mas que funcionou como a primeira experiência, um ensaio

4 Em plena sintonia de pensamento, o poeta pergunta: "O tempo cai, degrada-se no espaço, o íntimo desenvolve-se em episódio, o centro alastra à circunferência. A concentração temporal seguida do abandono, queda espacial, não é bem uma visão bergsonista?", A Águia, 2.a série, n. ${ }^{\circ} 48$, p. 181.

5 A Águia, 2. a série, n. ${ }^{4}$ 48, p. 181.

6 Convém ressalvar aqui que Álvaro Pinto foi a alma organizativa do movimento e do seu órgão divulgador. 
do grupo para o trabalho de maior fôlego que se seguiu. A Nova Silva adoptou como lema Libertas?.

Seguindo um texto fundador aí publicado por Leonardo Coimbra, encontramos algumas pontes com o pensamento do movimento da Renascença, do qual ele próprio viria a ser considerado o principal filósofo.

Eu vi a Vida gloriosa erguer-se no horizonte da minha alma oculta. Por um recolhimento contemplativo e extático tinha esquecido o homem e quase acendia a estrela do meu destino cósmico. Nesse momento criador vi a essência, a unidade original e eterna, através a acidentalidade humana sensível. Eu era envolto em sonho e em luar. O meu corpo conhece a lua, lembrava-se e a alma era cheia de saudades. Em mim um clamor ardente de vida, em minha carne um gesto criador, de balbuciante mistério. Senti então o poder da carne reveladora. ${ }^{8}$

Através desta prosa poética, revelavam-se os contornos do que viria a ser a sua base filosófica: o criacionismo espiritualista e personalista. $O$ seu universo era uma sociedade livre, de consciências, e a consciência feita pessoa, traduzida em actividade livre e criadora. Sob a influência de Renouvier ${ }^{9}$, e na esteira de Henri Bergson, considerava o acto criador como sendo a libertação da consciência que percorria a matéria, e se, por um lado, o conhecimento do mundo sensível era a inserção da alma na mortalidade da matéria, seria também, por outro, na fluência da matéria que se revelava a serena iluminação do espírito. A partir de um determinado plano, a diferença fugia à natureza das coisas para se centrar, enquanto actividade uniformizadora, na dualidade de sentido.

O vitalismo personalista desta filosofia revelava-se, ainda, considerando que o amor, a morte, Deus, o universo não eram puras ideias, mas vivências, formas de existência, desafios em que o homem singular se projectava com tudo aquilo de que era feito e o caracterizava. Contrariando o que considerava o raciocínio especulativo da filosofia pós-kantiana, considerava o principal trabalho do filósofo procurar, sob os artifícios

7 "Libertas. Sem servilismos de programas, de escolas, de dogmas - absolutamente livres de preconceito obedeceremos tão-somente aos impulsos da razão incoercível e indomada! Libertas! Na luta das paixões, que convulsionam a Humanidade, será essa palavra fecunda o estímulo da nossa actividade. A directriz do nosso esforço. Libertas! Sim, liberdade e com ela o supremo Bem, a suprema Justiça.,"Nova Silva, n. ${ }^{1}$, p. 1.

8 Nova Silva, n. ${ }^{\circ}$ 2, p. 10.

9 «La connaissance de la personne en tant que conscience et volonté est le fondement de toutes les connaissances humaines», Charles Renouvier, Le Personnalisme, Félix Alcan Éditeurs, Paris, 1903, p. 1. 
deformadores da representação, os dados imediatos da consciência. As intuições racionalizadas davam a conhecer a realidade do pensamento sob a forma de noções. Sendo que nada era em si e por si, a realidade era o máximo racional de sistematização de noções ${ }^{10}$.

Essência, existência e vivência comungavam em diferentes graus ou planos da integralidade da pessoa, do mundo e do cosmos. O instante, se vivido a partir da vida íntima do ser em comunhão com os vários planos, seria um momento de integral realidade.

Esta ligação entre a ordem pessoal, planetária e cósmica prendia-se directamente com conceitos de imaginário que davam os primeiros passos na psicologia e na psicanálise. Bergson, em sintonia, desenvolvia na sua ideia da "Durée" esta noção de algo que permanecia e transportava as leis universais, nos níveis da consciência de cada um, reveladas pela experiência; como uma tensão entre o que estava determinado e os mecanismos da acção livre, elas funcionavam como alavancas motoras da vida, o élan vital ${ }^{11}$.

Neste sentido, também para Leonardo Coimbra, as formas de objectividade que o plano cósmico ia organizando, uma vez que a consciência reflectida era uma das suas criações, iam desde a actividade mecânica, enquanto esquema de agir social, pela herança e memória biológica, até à clara consciência que um ser toma de si e do seu Universo.

Sentir e imaginar comungando da mesma natureza revalorizavam assim a razão na sua apreensão reflectida da realidade. Logo, o pensamento era criacionista, não porque criasse a realidade, mas porque a sua adaptação à vida social era obra da sua liberdade efectiva, isto é, da sua acção solidária, tornando-se, por tal, numa permanente criação.

Exterioridade e interioridade estavam em comunicação como rios que misturam as águas no campo das consciências: "Quando digo que existe é o universo inteiro que pela minha boca vem falar dizendo: Consinto. Se digo 'eu', é o infinito que fala um 'nós'

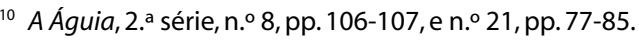

11 «À cette question spéciale nous avons répondu jadis en définissant l'être vivant par une certaine puissance d'agir en quantité et en qualité : c'est cette action virtuelle qui extrait de la matière nos perceptions réelles, information dont elle a besoin pour se guider, condensations, dans un instant de notre durée, de milliers, de trillions d'évènements s'accomplissant dans la durée énormément moins tendue dans les choses; cette différence de tension mesure précisément l'intervalle entre le déterminisme physique et la liberté humaine, en même temps qu'elle explique leur dualité et leur coexistence.», Henri Bergson, La Pensée et le mouvant: essais et conférences, Presses Universitaires de France, 1950, p. 61.
} 
que os meus ouvidos não escutam, mas que o corpo obediente às ligações gravíticas respeita e conhece."12

Recorrendo a Bergson, podemos reforçar esta ideia:

Sans doute enfin l'univers matériel défini comme la totalité des images est une espèce de conscience, une conscience où tout se compense et se neutralise, une conscience dont toutes les parties éventuelles, s'équilibrant les unes les autres par des réactions toujours égales aux actions, s'empêchant réciproquement de faire saillie. ${ }^{13}$

Esta memória consciente e genésica estava presente nos contornos atribuídos à Saudade, como teoria de conhecimento de si próprio e dos homens:"Conhecer é sempre anunciar na transitividade dos mundos a estabilidade da ideia (...) o conhecimento é pois fundamentalmente uma obra de saudade (...) saber não será recordar; mas é, pelo menos, inserir no fluxo sensível a firmeza de um juízo que o domina." ${ }^{14}$

Utilizando um tempo psicológico de retorno, Bergson ${ }^{15}$ veria a memória como a ligação entre um passado que não era mais um presente, mas sim um futuro que o aguarda.

O filósofo português daria desta ideia de memória/saudade uma imagem dramatizada. “O amor perfeito é Deus, perfeita identidade do inteligível com o intelecto; o amor humano seria, fora da beatitude, a coincidência da ideia com o objecto, seja na vida social o acordo de todas as ideias sobre o objecto social, que é a própria vida da sociedade humana. ${ }^{116} \mathrm{E}$ desse combate consigo próprio e que envolvia o todo surgiria, pela via da concretização do amor como a via possível, a unidade original e eterna ${ }^{17}$.

12 A Águia, 2. ${ }^{\text {a série, n. }}{ }^{\circ}$ 14, p. 67.

13 Henri Bergson, Matière et mémoire, Libraire Félix Alcan, Paris, 1928, pp. 262-263.

${ }^{14}$ A Águia, 3. ${ }^{\text {a }}$ série, n. ${ }^{\text {os }} 7-12$, p. 163.

15 «Mais pour toucher la réalité de l'esprit, il faut se placer au point où une conscience individuelle, prolongeant et conservant le passé dans un présent qui s'enrichit, se soustrait ainsi à la loi lui-même de la nécessité, qui veut que le passé se succède sans cesse à lui-même dans un présent qui le répète simplement sous une autre forme, et que tout s'écoule toujours. En passant de la perception pure à la mémoire, nous quittions définitivement la matière pour l'esprit.», Idem, ibidem, p. 263.

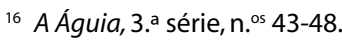

17 "Já viram essa terra seca e mirrada que um estio voraz queimou com beijos de fogo? Aquela desolação inquieta não lembra uma face severa que sente e inutilmente procura falar uma alma inundada de enternecimento. Eis o que é uma virgem amorosa. Terra estéril e mísera e que impetuosa torrente de vida não referve e tumultua a dentro do cárcere de um mentiroso poder! Assim era então junta a mim a mais próxima irmã do meu destino. Os seus flancos vibráteis, o seu ventre misterioso, os seus peitos húmidos, 
Sendo a filosofia de Leonardo uma filosofia de liberdade e sendo esta relativa na ordem humana, pela remoção dos seus limites, aparecia agora como força espiritual ou amor, produto da experiência humana, logo cooperante e libertadora. A impossibilidade de uma consciência solitária ser criadora baseava o processo psicológico da construção da personalidade como obra de conhecimento e liberdade ${ }^{18}$.

Esta liberdade conduzia à percepção consciente que, segundo Bergson, caminhava em direcção à matéria, ao mesmo tempo, ou na medida em que nos desembaraçássemos daquilo que se pode designar como juízos prévios da acção. No entanto, todo o acto ou pensamento libertador comungava com os vários planos ou ordens numa contribuição automática, mas também desejada.

Para melhor explicar o movimento de ascensão espiritual experimentado pelo jovem Leonardo na Nova Silva, vamos mais uma vez recorrer a Henri Bergson, que Leonardo Coimbra, bem como toda a sua geração, tanto estudou e admirou.

Non seulement, par sa mémoire des expériences déjà ancienne, cette conscience retient de mieux en mieux le passé pour l'organiser avec le présent dans une décision plus riche et plus neuve, mais vivant d'une vie plus intense, contractant, par sa mémoire de l'expérience immédiate, un nombre croissant de moments extérieurs dans sa durée présente, elle devient plus capable de créer des actes dont l'indétermination interne, devant se répartir sur une multiplicité aussi grande qu'on voudra des moments de la matière, passera d'autant plus facilement à travers les mailles de la nécessité. Ainsi, qu'on l'envisage dans le temps ou dans l'espace, la liberté parait toujours pousser dans la nécessité des racines profondes et s'organiser intimement avec elle. L'esprit emprunte à la matière les perceptions d'où il tire sa nourriture, et les lui rend sous forme de mouvement, où il a imprimé sa liberté. ${ }^{19}$

Para o filósofo português, esse impulso vital conduzia a Deus, e foi essa visão panteísta que a entrega integral ao êxtase sensual do amor lhe proporcionou ${ }^{20}$.

os seus olhos de fogo, as suas húmidas pálpebras diziam o mais eloquente pedido, erravam, na órbita fatal da matéria, para os meus braços trémulos e magnéticos!,"Nova Silva, n. ${ }^{\circ}$ 2, p. 10.

${ }^{18}$ A Águia, 2.a série, n. ${ }^{\circ}$ 8, pp. 106-107, e 3. a série, n. ${ }^{\circ 5} 9-10$, pp. 81-89.

19 Henri Bergson, idem, ibidem, pp. 278-279.

20 "E eis o que ouvi ao seu corpo sonoro e luminoso: Na eternidade copularam as estrelas e geraram-me em sonho. Sou o sonho. Falo luz, são astros os meus gestos. Das entranhas da terra subi em luar, na terra fiquei em sonho e sou o luar das almas. Numa noite tempestuosa, cheia de clamor das formas rezando a imperfeição, fulgurei nos olhos de um tigre. Oh! que pavor e assombro havia na minha prece! lluminei um dia uma serpente e subi aos céus nas asas duma ave. Criei uma alma, indaguei a vida e fui homem. Como tem sido dolorosa e bela a minha peregrinação humana! Esqueceu-me o passado, ignoro a vida, 
Duma queda de Deus ${ }^{21}$ resultara a criação, na qual o Bem e o Mal lutavam. Numa perspectiva de economia do mal, o homem devia associar-se a esta luta e com o seu esforço colaborar na redenção de si mesmo, do cosmos e do próprio Deus. Nesse sentido, Criador e criatura estavam indissoluvelmente ligados por leis universais, mas o ponto de ligação construía-se transcendentalmente a partir da vivência para a essência e evoluiria quer por abstracção do particular, esvaziando-o de conteúdo, quer em sentido contrário, adicionando particularidades ao máximo generalizante. $O$ ser puro encontrar-se-ia como princípio de toda a realidade, excedendo-se no todo a soma das partes, como bem absoluto.

Os cinco números publicados da Nova Silva representavam a tendência anarquista e anticlerical do grupo originário da Renascença Portuguesa, então dominante no meio estudantil. $\mathrm{O}$ anarquismo desta geração tinha uma finalidade personalista e solidária, opondo-se, no entanto, a qualquer tipo de colectivismo político. Com Proudhon atribuíam à justiça, cuja dimensão em abrangência conceptual assinalavam através da maiúscula, uma acção regeneradora. Com Tolstoi adoptavam uma atitude pacífica na aceitação do amor na sociedade, para alguns também o anseio de retomar por essa via a pureza do cristianismo primitivo. E com Kropoktine encontravam na origem de uma consciência moral generosa o auxílio mútuo e solidário.

A revista anunciava ainda os preparativos para a formação de uma escola livre que não chegou a concretizar-se, mas que prenunciava os projectos de educação alternativa, tão caros à Renascença. Divulgava-se também na Nova Silva a constituição de um grupo com sede no Porto chamado Amigos do $A B C$, à semelhança do grupo francês (Les Amis de L'Abaissé) de Os Miseráveis de Victor Hugo. Este grupo satisfez a necessidade de intervenção social suprapartidária sentida pelos jovens publicistas. Entretanto, a agudização da situação política veio a dispersar este núcleo, no qual só Campos Lima e Cristiano Carvalho continuaram, mas desta feita em ligação com o anarco-sindicalismo. A maioria dos outros jovens fora ganha para a militância republicana, sobretudo a partir das greves estudantis de 1907.

\footnotetext{
não compreendo o Universo e, no entanto, há em mim, insofrida e insaciável, uma imensa ânsia de luz, de verdade, de comunhão. Criei a alma e fui sua vítima. Como as há estreitas, tenebrosas e mirradas! Aspiro, soluço, sofro e não posso revelar-me, o cárcere é opaco, não posso revelar-me. Há almas ligeiras, simples, etéreas, puras e luminosas. Aí floresço as flores eternas do ideal. Sou a nuvem que leva o povo de Moisés à terra da promissão. Sou o sorriso da criança e a suavidade de Cristo, a timidez da virgem e a humildade do mendigo, a quimera do poeta e a loucura do herói. Incendeio as almas e ergo-as na plenitude da sua beleza, aproximo-as na nudez da sua absoluta verdade. Por mim se conhecem as almas, num olhar possuem-se no mais completo contacto", Nova Silva, n. ${ }^{\circ}$ 2, pp. 10-11.

${ }^{21}$ Renouvier, na obra sobre o personalismo, dedica um capítulo ao problema da Queda de Deus.
} 
Leonardo Coimbra (que só se filiará no Partido Republicano em 1914) e Jaime Cortesão aderem à República, com a esperança de que o exercício da liberdade e dos direitos democráticos contribuísse, na linha defendida por Sampaio Bruno, para uma evolução consciente de cada um no sentido da autonomia individual, e consequente maturidade política e intelectual. Leonardo Coimbra, anos mais tarde, em 1925, na revista A Águia, em polémica com o Integralismo Lusitano, reforçava esta atitude expectante na raiz da adesão ao Partido Republicano:

Sem obstáculos, teríamos a sociedade ideal, anarquista, do trabalho colectivo em acordo de liberdades subindo (...) é um ideal.Tentemo-lo por tendência e aspiração: dará a democracia benévola, atenta, fazendo da compreensão, da expressiva inteligência, a alma do seu esforço. E não se diga que esta Democracia está em crise, ela é até a alma dos outros movimentos sociais que julgam contrariá-la. ${ }^{22}$

Pouco depois de implantada a República, publicava-se o primeiro número da primeira série de A Águia, no dia 1 de Dezembro de 1910, fundada e dirigida por Álvaro Pinto, regressado da Madeira e entusiasmado com a vitória republicana. Nela participou todo o núcleo principal da futura Renascença Portuguesa: Jaime Cortesão, Leonardo Coimbra, Augusto Casimiro, Mário Beirão, Afonso Lopes Vieira, Raul Proença, António Sérgio, mas também Guerra Junqueiro, José Teixeira Rego, Sampaio Bruno, Manuel Laranjeira, Miguel de Unamuno, Raul e Júlio Brandão.

Tolstoi, Victor Hugo e António Nobre tiveram homenagem destacada nesta série que constou de dez números. Pascoaes, na direcção cultural da revista, anunciou o seu movimento poético-filosófico, com expressão original da saudade na essência do Espírito Lusitano, contendo em si o renascimento da Raça. Dá-se nesta série um encontro poético entre Jaime Cortesão e Teixeira de Pascoaes, no poema "A humanização da natureza", e aquele aderiu à concepção original e transcendente do ser lusitano.

Terminados os dez números que Álvaro Pinto se tinha proposto, a série acaba, e Jaime Cortesão escreve a Álvaro Pinto, informando-o do quanto era lamentado, nomeadamente em Lisboa, o fim da revista. Perante este facto, teve a ideia da criação de um movimento cultural que congregasse os intelectuais que andavam dispersos e que de alguma forma contribuísse positivamente para a situação do país,"com uma

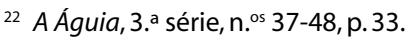


acção social orientadora e educativa"23. Nesse sentido, escreveu também uma carta a Raul Proença, convidando-o a elaborar um programa-manifesto que desse corpo à sua ideia. A associação que lhe propunha deveria ter três sedes, em Lisboa, Porto e Coimbra, para que juntasse os intelectuais e artistas de todo o país ${ }^{24}$.

Contactado Teixeira de Pascoaes, este propôs que a primeira reunião se realizasse em Coimbra. Assim foi, mas de Lisboa ninguém compareceu, e o poeta ficou encarregue da redacção do manifesto de apresentação. Cortesão resumirá mais tarde as conclusões da reunião de Coimbra:

Aí se lançaram as bases da nova organização que se propunha dois fins essenciais: restituir Portugal à consciência dos seus valores espirituais próprios; e promover em todo o país, por meio de uma revista, que fosse o órgão do movimento, de edições de livros, Universidades Populares, conferências, exposições e concertos, uma profunda acção cultural, junto de todas as camadas sociais. ${ }^{25}$

Na reunião seguinte em Lisboa, sem a presença de Teixeira de Pascoaes, foi lido o seu manifesto, que não obteve o apoio dos lisboetas. Raul Proença e António Sérgio protagonizavam o desacordo que, resumidamente, se baseava na crítica de que onde se lia lusitanismo deveria ler-se europeísmo.

Apesar de Proença ter chegado a escrever um manifesto alternativo, nenhum dos dois seria publicado ou assumido como programático para o movimento da Renascença Portuguesa. Só mais tarde foram divulgados na Vida Portuguesa, revista que se publicou entre 1915 e 1921, sob a direcção de Jaime Cortesão e destinada a analisar, promover e publicitar as actividades educativas e culturais do movimento.

A Águia inicia a 2. a série em Janeiro de 1912 e, até à 5. a série ou ano XX em 1932, será

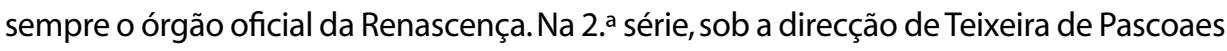
até 1917, Álvaro Pinto desde essa data até 1921, e na 3. a série sob a direcção de Leonardo Coimbra de 1922 a 1927, a revista conheceu o momento de maior divulgação literária e doutrinária, durante o qual se procurou, sem nele se esgotar, credibilizar e dar consistência ao Saudosismo, como meio para o renascimento da "Pátria Portuguesa":

23 Jaime Cortesão, in Alfredo Ribeiro dos Santos, A Renascença Portuguesa, Fundação Eng. António de Almeida, 1990, p. 80. Para a história do movimento, ver também Paulo Samuel, $A$ Renascença Portuguesa, Fundação Eng. António de Almeida, 1990.

24 "Ora o que há a fazer é essa obra titânica de orientar esta gente, de criar um público consciente e ilustrado e de impor artistas e intelectuais. Este é o fim principal, que a meu ver a Associação deve ter...", Jaime Cortesão, idem, ibidem, p. 78.

${ }^{25}$ Jaime Cortesão, idem, ibidem, p. 82. 
A Saudade é o próprio sangue espiritual da Raça; o seu estigma divino, o seu perfil eterno. Claro que é a saudade no seu sentido profundo, verdadeiro, essencial, isto é, o sentimento-ideia, a emoção reflectida, onde tudo o que existe, corpo e alma, dor e alegria, amor e desejo, terra e céu, atinge a sua unidade divina. Eis a Saudade vista na sua essência religiosa, e não no seu aspecto superficial e anedótico de simples gosto amargo de infelizes. É na Saudade revelada que existe e razão da nossa Renascença original e criadora. ${ }^{26}$

Assim, se a Renascença Portuguesa não era um movimento político, foi de facto um movimento politizado e politizante, isto é, a alternativa proposta à sociedade portuguesa passava necessariamente por uma organização diferente, porque se corporizava num novo tipo de político ${ }^{27}$.

Esta visão integrada do homem e da sociedade permitiu-lhes entender a importância da educação, do ensino e de novas formas de pedagogia, o que era, de resto, uma agenda comum à intelectualidade dispersa que pretendiam congregar; melhor dizendo, a ideia de uma elite preparada que assumisse a missão de mudar um país, dar-lhe uma identidade renascida e um caminho de conhecimento moral e filosófico foi o pilar do movimento Renascença Portuguesa e a vocação do seu órgão divulgá-los.

Leonardo Coimbra e Teixeira de Pascoaes, o primeiro através da filosofia, o segundo, da poesia, intentaram uma explicação totalizadora para o desvendar de um horizonte futuro, a reconhecer como tendo sido sempre o dos portugueses.

Estabelecendo pontes com a política que se pretendia, Leonardo Coimbra veria na democracia a expressão da sua filosofia de liberdade, demonstrando o seu valor e a eficácia do seu espaço, na relação inteligente que permitia estabelecer entre liberdade e autoridade ${ }^{28}$. Demarcando-se do autoritarismo, apresentava a ideia de autoridade como acordo construído pela experiência vivida em comum, que equivalia, no

26 Teixeira de Pascoaes, A Águia, 2. a série, n. ${ }^{\circ}$ 1, p. 2.

27 "Associação mais para actuar a distância pelo pensamento e pelo sentimento, a Renascença Portuguesa, revista mais de ideias e sentimentos, $A$ Águia, não deixará todavia aquela Associação, como não deixará esta revista, de olhar para as necessidades do momento e será, quanto possa, um órgão de crítica e reconstrução imediata da vida social e política e da nação. Tendo como destino supremo a contribuição para a nova consciência intelectual, do homem e do cidadão, não pode, no entanto, esquecer os males imediatos e terríveis que oprimem a pátria e, para que o remédio apareça, dará o que no seu esforço e saber possa existir", Leonardo Coimbra, A Águia, 3. a série, n. ${ }^{\circ}$ 1, p. 7.

28 "A república que quase todos nós fundadores da Renascença, sonhamos bela e pura, cheia de feridas (...) teremos de servir a república com a consciência de democratas que sabem o valor e o significado da democracia e não querem uma república de formalismo político, sem conteúdo social de melhor justiça, mais heróica fraternidade, mais lúcida compreensão e esforço de progresso no bem," A Águia, 3. ${ }^{a}$ série, n. ${ }^{\circ}$ 1, p. 6. 
espaço da democracia, o único possível para a existência da autoridade consentida porque processo de construção permanente e colectivo, à ideia de justiça ${ }^{29}$.

Como revista cultural, celebraram a vida ao reverem-se no vitalismo criacionista e, sobretudo, na Matéria e Memória de Henri Bergson, na saudade genésica como característica impressa na alma portuguesa alcançável através de um percurso de autoconhecimento pessoal e colectivo, e atingível de imediato pela expressão poética porque, segundo Pascoaes, o saudosismo era revelado ao poeta ou à alma poética. Daqui a importância e o inegável peso da poesia na revista.

Assumindo-se como espaço de debate e reflexão, as páginas da revista foram muitas vezes palco de polémicas que não raro opunham colaboradores e membros do Movimento.Se Fernando Pessoa, após a publicação na revista de uma série de artigos, fundamentando o surgimento do que considerava ser a nova literatura portuguesa ${ }^{30}$, se afastou do movimento para abraçar um projecto futurista corporizado na revista Orpheu, outros exemplos houve em que os desacordos não motivaram afastamento.

Neste sentido, António Sérgio foi um caso paradigmático de alguém que participou activamente ao longo de toda a publicação, que editou parte importante da sua obra pedagógica e ensaística através da editora da Renascença e que no entanto sempre se demarcou do saudosismo ${ }^{31}$ e da visão transcendental de ser português. Acreditava no poder/dever das elites intelectuais e na missão que tinham a cumprir em Portugal como em qualquer outro país, mas de forma coordenada e solidária.

Em consonância, defendeu uma nova maneira de fazer História. Distanciando-se da historiografia que procurava edificar através de um passado heróico ou exemplar, cruzava os factores geográficos e económicos em termos globais para através da análise comparativa teorizar, interpretando à luz do conhecimento presente, sobre os erros e as virtudes a emendar e a preservar, respectivamente, no futuro ${ }^{32}$.

Foi ainda a única voz que se ergueu contra a participação portuguesa na Grande Guerra, desmistificando os laços de raça ou consanguinidade latina versus germânica,

29 "De maneira que os dois modos de fazer o acordo da Autoridade com a Liberdade são duas tendências ideais: uma que apresenta o facto da Autoridade como força social impondo-se às liberdades, outra que vê no tempo a génese dessa Autoridade por actos anteriores de inteligência e acordo", $A$ Águia, 3. a série, n. ${ }^{\text {os }} 37-48$, p. 37.

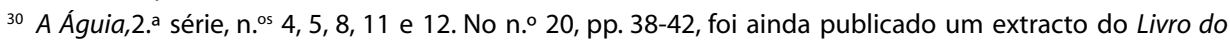
Desassossego.

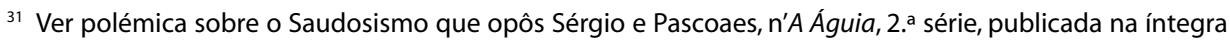
em Paulo Samuel, $A$ Renascença Portuguesa, 1990.

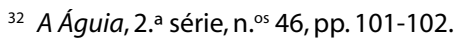


sobrepondo-lhes a moral e o direito, e a consequente fraternidade, como únicas formas de validação legítima de povos e nações ${ }^{33}$, que era, como se pode ver, e como António Sérgio também viu, um problema que, para além de político, era cultural. Uma ideia de cultura como algo vivo e em permanente construção levou-o a defender um renascimento da cultura portuguesa ${ }^{34}$ através de uma educação que não se limitasse à transmissão de um amontoado de conhecimentos, mas que desempenhasse um papel libertador no sentido da autonomia e do encontro entre o indivíduo e uma moral cívica ${ }^{35}$.

Colocando a reforma da educação como base para qualquer outro tipo de reforma que se quisesse efectuar em Portugal ${ }^{36}$, acreditava que o desenvolvimento e o progresso das ciências deveriam ter em conta ou por medida o bem comunitário, isto é, que nem sempre aos progressos científicos correspondiam os progressos da razão humana ${ }^{37}$, no que se compaginava com o espírito da revista e do seu núcleo fundador.

António Sérgio começou a sua colaboração em AÁguia em 1911, estreando-se como poeta $^{38}$, pelo meio e em tempo de exílio sidonista no Brasil. Em conjunto com Álvaro Pinto, iniciou o movimento equivalente à Renascença Portuguesa no Rio de Janeiro, - Anuário do Brasil, sendo a partir dessa cidade que A Águia era editada ${ }^{39}$. Mais tarde, quando a revista Pela Grei, fundada com Ezequiel de Campos, teve problemas de publicação, a revista da Renascença abriu uma secção destinada à continuação da publicação Pela Grei nas suas páginas ${ }^{40}$. António Sérgio terminou a sua colaboração em 1932 com um apelo à democracia como ideal de partilha, de participação e representação e defendendo a consequente adequação das instituições públicas, educacionais e políticas a esse ideal."Regime democrático da sociedade, por isso mesmo, é que uma viva moral, espiritual e não uma matéria que se conserve por si, pela força da inércia, tem de ser instaurado, continuadamente, pela propaganda e pelo jornal diário, pelo livro de doutrina e pela escola pública, num esforço contínuo de criação social."41

Retirando o balanço das cinco séries, facilmente constatamos a importância desta revista pelo cumprimento e, em muitos casos, o ultrapassar dos objectivos a que se

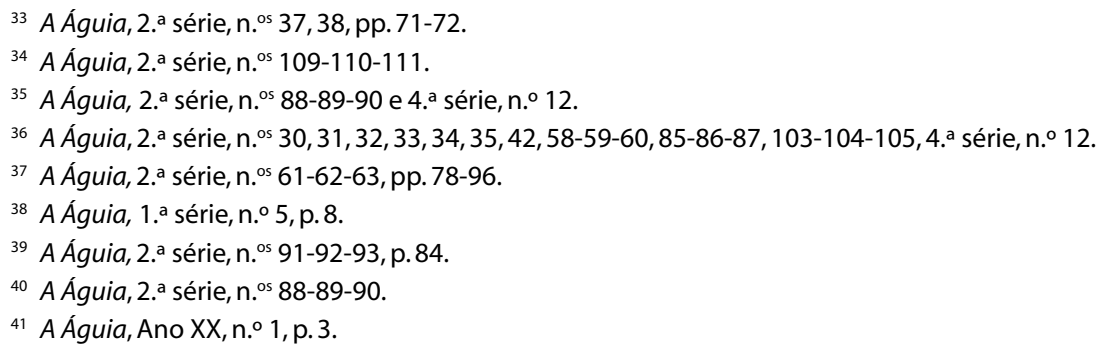


tinha proposto. Toda a vanguarda intelectual das mais diversas áreas da arte à ciência encontrou espaço para expor os seus estudos, teorias e críticas, já que, muito embora Sérgio fosse o paradigma de um apoio polémico à publicação, muitos outros debates animaram as páginas de $A$ Águia nas mais diversas áreas, desde a literatura, a filosofia, a história, as artes e a economia às novas ciências sociais e humanas como a antropologia, a psicanálise, a filologia e linguística, a pedagogia.

Em defesa de um novo enquadramento político e social, não será demais ressaltar que o que à primeira vista parecia uma enumeração de saberes compartimentados e antigos adquiriu na revista um sabor de novidade transdisciplinar, isto é, traduziu-se na procura de novas formas de conhecer, pela compreensão e interpretação do todo, como instrumento ou ferramenta de aplicação e interligação inteligente dos saberes particulares, ao que não foram alheios o conhecimento dos passos dados pela física, a matemática, a psicologia ou a psicanálise coevas.

A divulgação de temas e teorias de vanguarda desembocava não raras vezes na crítica como forma autónoma de apreciação e validação da obra intelectual, que foi outro dos aspectos importantes desenvolvidos pela revista, desde a recensão à divulgação crítica de acontecimentos culturais, editoriais ou pedagógicos dentro e fora do movimento da Renascença Portuguesa, ou do país, com especial destaque para o Brasil. Estes aspectos permitiram alargar qualitativamente o horizonte de intervenção da publicação.

Por outro lado, a promoção e a publicitação de revistas de especialidade ou generalistas oriundas de todo o mundo, em especial do continente americano, que tal como A Águia procuravam manter-se no acompanhamento e divulgação de trabalhos de vanguarda, completavam o papel que pretendiam em correlação com os objectivos anunciados de acordo com a filosofia defendida. $O$ conjunto de autorias e temáticas foi assim completado por uma geografia de produção intelectual que muito contribuiu para o sucesso e a perenidade da revista.

A partir destes pressupostos, a mensagem cultural e política que convém reter fundamentava-se numa ideia de liberdade e na forma do seu aperfeiçoamento, o espaço da democracia. A missão desinteressada de uma elite intelectual que era preciso mobilizar, e a cujos saberes urgia dar sentido, através do exemplo da acção concreta e da partilha alargada, implicava uma nova definição, quer de intelectual, quer de político. Foi por essa via que o Movimento e a Revista entraram, e foi nesse contexto que, apesar das diferenças, se conseguiram alianças.

Com Leonardo Coimbra, claramente, a liberdade era uma descoberta interior provocada e alimentada pela exterioridade de todas as vivências, enquanto para António 
Sérgio era uma construção intelectual, conquista de uma maturidade autónoma e racional, educativamente assistida.

O personalismo do filósofo do Porto colocava a jusante, isto é, como primordial ou necessária a ligação entre o plano pessoal e universal, numa organicidade genética e espiritual que a memória traduzia em identidade e em liberdade; quer dizer, entre o determinismo físico e a liberdade humana existiam diferenças de qualidade e duração que projectavam o primeiro na finitude e a segunda no infinito idealizado. O vitalismo completava a compreensão do aqui e do agora nos vários graus e planos, fundamentando a liberdade com a autoridade cooperante, porque vinda de um cada vez maior número de experiências reais, ou vividas, no encontro das inteligências com o seu objecto. O pluralismo que presidia a esta filosofia, relativo e progressista, partia da imutabilidade do seu processo de desenvolvimento, um espaço-tempo desigual mas combinado, que equacionava a partir da experiência todas as dimensões do ser e do dever ser, como formas inseparáveis de construção da verdade humana e base da vida social.

António Sérgio idealizava a democracia como fim, como possibilidade de sucesso para a sociedade humana, numa espécie de revolução permanente de actualizações políticas e institucionais em consonância com o aperfeiçoamento moral e espiritual dos cidadãos, criando automaticamente condições para o desenvolvimento do princípio da liberdade e da igualdade de condições externas. Educar, dever da elite intelectual, era sobretudo preparar para a participação cívica, logo cooperativa, para o espírito de iniciativa e trabalho, tendo como produto mentalidades críticas e experimentais. Esta era a medida, o homem livre e racional, que não se compadecia ou vergava perante consanguinidades rácicas, ou fronteiras estabelecidas pela história. $\mathrm{A}$ identidade construída, não como particularidade transcendente, mas como projecto consciente e harmónico entre pensamento e acção, no espaço da universalidade humana, conduzia a um cosmopolitismo que não negava a nacionalidade, mas que a via antes de mais como um processo de conquista de adesões político-culturais no sentido lato.

Partindo do homem universal, ou negando-o a priori para o encontrar em cada particularidade, era no plano da existência e na validação da experiência que os caminhos se encontravam, não fora Kant afinal a figura tutelar. Assim, para além do importante debate intelectual, em torno das questões filosóficas que fundamentavam a liberdade ou a democracia, distinguia-se como prova de credibilidade sine qua non uma postura moral daí decorrente. 
Do conturbado período da I República, o senso comum não reteve o real valor do debate em torno do pensamento e acção democráticos, que davam os primeiros passos. Julgamos não arriscar erro se, ao pegar neste movimento, na sua revista e nas que se seguiram animadas por estes pensadores e, caminhando por aí, chegarmos a encontrar um fio condutor até ao 25 de Abril 1974. Não será demais terminar, ressalvando a importância de um estudo desse tipo para uma maior compreensão e participação positiva nos desafios da actualidade. 